\title{
Student Self-Esteem and Parental Involvement in Students Academic Performances
}

\author{
Jerald C. Moneva \\ Department of Education-Mandaue City Division \\ Mandaue City, Cebu, Philippines \\ E-mail: Freezingfire1979@gmail.com \\ Mark Roed A. Villaro \\ Jagobiao National High School \\ Jagobiao, Mandaue City, Cebu, Philippines \\ E-mail:markroed996@gmail.com \\ Marsha H. Malbas \\ University of Visayas \\ Mandaue City, Cebu, Philippines \\ E-mail: marsha_m@yahoo.com
}

Received: February 13, 2020 Accepted: May 20, 2020 Published: June 20, 2020

doi:10.5296/ijssr.v8i2.17219 URL: http://dx.doi.org/10.5296/ijssr.v8i2.17219

\begin{abstract}
Self-esteem is a feeling of having respect and abilities. While parental involvements the amount of participation of a parent when it comes to schooling and child's life. In school was conducted to know the association between the two variables. This study used descriptive correlation design between self-esteem and parental involvement. The respondents of this study are the Senior High School Students of Jagobiao National High School. Questionnaire was the chosen research instrument of the study and the relationship between the dependent and independent variable was determine using chi-square. The data revealed that the self-esteem of the students affects their academic performance; students with high self-esteem tend to be more confident than the students who have low self-esteem.
\end{abstract}




\section{Macrothink}

International Journal of Social Science Research

ISSN 2327-5510 2020, Vol. 8, No. 2

Furthermore, it is proven that student's self-esteem and parental involvement are correlated to each other. Those parents who motivate their child can lead to have a higher self-esteem. The study reveals that having a higher self-esteem and having a parental involvement helps to mold and to attain higher academic performance by the students in school.

Keywords: academic achievement, academic performance, confidence, motivation, parental involvement, self-esteem 


\section{Rationale}

Self-esteem and parental involvement in student's academic performance are about how to improve or develop the student's performance in school. If a student has the high self-esteem and parental involvement it can change and develop the students' attitude in academic performance. Likewise, parental involvement has an impact of the student's self-esteem for their academic performance whereas; self-esteem is one of influential factors which can affect student's academic performance. It has deemed that high self-esteem can lead to high academic performance.

In general, high self-esteem help individuals to view themselves as active and capable persons to promote changes through effort and set high goals which cause learning new things. Having a high self-esteem can act an important role in academic achievement, social and personal responsibility. In addition, students with high academic achievement tend to feel more confident in contrast to these who lack of confidence achieves less.

If a student has high self-esteem can resolve the conflict with other student and can oppose to deal with the problems. The parents can mold their children in relation to their academic performance. The parents can be motivators to keep or push their children to attain high academic performance unless with lack of concerns for their academics. If a parent put a pressure on their children to excel at school and engage in their children's homework processes can lead lower academic competence, hence, and lower achievement.

In the study, the researcher will learn the correlation between the self-esteem and parental involvement. The result of the study will be the basis if there is a relationship between the two. Additionally, the result of this study is helpful to the researcher, it provides them knowledge and understanding about the two variables. It intends to know the correlation between student's self-esteem and parental involvement in student's academic performance among senior high school in Jagobiao National High School.

The study intends to know the level of student self-esteem and parental involvement in students' academic performances and their association.

\subsection{Theoretical Background}

The study supported the Theory of Self-Esteem by Alicia D. Cast and Peter J. Burke in 2002 and Epstein's Framework of Six Types of Involvement by Joyce L. Epstein. Cast and Burke. Cast and Burk (2002) proposed a theory of self-esteem, the theory tackled or conceptualized as an outcome, motive and buffer.

Self-esteem produced in part through self-verification because it motivates individuals to form and maintain relationship that verify identities. Students need a high self-esteem to enhance or perform for their academic performances. Students gain self-esteem through enhancement, but also through self-verification. It's possible that one can create or seek to enhance self-esteem by creating social relationships with individuals. Students must learn how to gain a high self-esteem in order to have a friendly competency with schoolmates and to avoid getting low self-esteem that affecting child's competency in school.

If a student has a higher self-esteem it may lead to a better and improve grades. Students must learn to socialize by other individuals to create relationship that can improve student's 
self-esteem. Students must have a high self-esteem to get high academic performance.

Joyce Epstein (2001) proposed a framework contains six types of involvement which are Parenting, Communicating, Volunteering, Learning at Home, Decision Making and Collaborating with Community. Parents can give awareness of family supervision or having a respect for parents. Parenting increases the positive personal qualities, habits, beliefs, and values taught by the family. Parenting includes the development of student's management for chores, homework and other activities. Monitoring the student's progression by their parents is needed. Parents and student need to pick up report card, it is important to know the progression of the student by having a conference with a teacher.

If a parent always monitors the child's progression it may help increase the academic performance of the student. It gives a positive quality to the student if he or she is guided always by the parents.

The two theories correlate with each other. It possibly reveals that there's a relationship between the student's self-esteem and the parental involvement. It is important to build a communication between the parents and child to create an involvement that can mold to attain self-confidence that will help them to make a progression on their academic performance.

\subsection{Statement of Purpose}

The study intends to assess the association between the level of student's self-esteem and parental involvement. In particular, the study seeks the answers of the following questions:

1) What is the level of self-esteem of students?

2) What is the level of parental involvement of the students?

3 ) Is there any association between self-esteem of student and parental involvement?

\subsection{Review of Related Literature}

The study self-esteem and parental involvement was supported by different articles and it serves as the basis to support the study "Student's self-esteem and parental involvement in Student's academic performance."

There's correlation between the self-esteem and academic performance (Madaugwu, 2014). In addition, students with high academic achievement tend to feel more confident in contrast to these who lack of confidence achieves less (Aryana, 2010). Self-esteem influences the student's academic performance and stress (Rosli, Ishack, Orthman, \& Lubis, 2011). Students who have a high self-esteem will go through a very excellent academic performance (Arshad, Zaidi, \& Manhood, 2015). Student who has higher self-esteem can influence the other students who have lack of self-esteem by persuading them to attain higher academic performance (Alias, 2009). Students who have more self-esteem intend more academic achievement than low academic achiever students (Tripathy, 2012). Having greater self-esteem can interact with other people effectively, they're confident in socializing (Greenacre, 2014). Study shows that the female respondents have more self-esteem than male respondents (Mello, Monteiro, \& Pinto, 2018). The components of academic achievement and self-esteem are significant (Doodman, Zadeh, \& Changizi, 2017). To increase the level of 
self-esteem, it's apparent that planning psychological interventions may be useful in promoting academic achievement (Alavijreh, Rajati, \& Limoee, 2018). There is inhibitor effect on academic performance if the student is lack of self-esteem (Nemotollahi, Tavakoli, \& Akbarzadeh, 2017). Students who have more self-esteem intend more academic achievement than low academic achiever students (Tripathy, 2012). To become a well-being individual, it needs to have self-esteem and social skills to improve one's performance (Ratnasari \& Adriansyah, 2014). A dependent attitude tends to have higher self-esteem (Sternke, 2010).

Parents who were always involved by their child's education is likely to have higher self-esteem (Gith, 2017). Receiving support and involvement from parents can create a higher self-esteem (Ruholt, Gore, \& Dukes, 2015). Parents taking control the homework of their students have better communication with their child (Fernandez-Alonso, 2017). In contrast, a student with potential at school suffers from their parents who lack parental involvement with their students (Obico, 2015). Academic achievement is definitely influenced by parental involvement, also with how school connects with the expectations of the family (Rogers, Theule, Ryan, Adams \& Keatling, 2009). It will take time to create a strong relationship the school and the parents (Vijaya, 2016). There is difference in parental involvement between economic status of poor and rich, wealthier family are most to be involved in their child's education than an impoverished (Hill \& Taylor, 2004). When parents involved themselves effectively in their child's education, this will give benefits to their child's school performance (Fan \& Williams, 2010). Parental involvement helps to mold their child, it helps to make learning for children and encourages them to work more (Ntekane, 2018). Parents should have the skills to foster both cognitive growth and achievement motivation so that their child tends to achieve more (Khajehpour \& Ghazini, 2011). Parents and schools may have partnership programs that can develop, implement, evaluate, and improve plans and practices encouraging (Durisic \& Bunijevac, 2017). Having parental involvement can be support strategy for improving secondary student's academic performance (Mcneal, 2014). Hence, previous study reveals that there's no significant influence on parental involvement and academic performance (Koskei, 2014).

\section{Research Method}

\subsection{Design}

This research study used descriptive correlation design of the two variables which are self-esteem and parental involvement in student's academic performance. The data were collected from the Senior High School students.

\subsection{Environment}

The Jagobiao National High School part of K-12 program and added the Senior High School and offers the following programs: ABM, GAS, HUMSS, STEM and TVL drafting. Last February 28, the Jagobiao National High School of the seal of excellence in Education Development of the Roman aboitiz Foundation, Inc. (RAFI-SEED). The research study conducted in the School of Jagobiao National High School in the North Road property of 


\section{Macrothink}

Jagobiao, Mandaue City.

\subsection{Respondents}

The respondents of the study were chosen among Senior High School students particularly in Grade 11 and Grade 12 students. There are 93 boys and 132 girls as respondents. The goal of researcher's respondents was 225 Senior High School students in Jagobiao National High School.

\subsection{Instruments}

In this research study the researcher intended to use a research tool which is checklist. Checklist type questionnaire composed of two variables. The first part of the questionnaire has 10 question which enables to answer the level of student's self-esteem while the second part of the questionnaire has 10 questions which enables to answer the level of parental involvement on student's academic performances.

\subsection{Data Gathering Procedures}

The researcher will ask permission to the teachers, school head and students. The researcher was approved. The respondents were given and guided by the questions and the researcher stated the objectives and the purpose of the study. The data depends on the answers of the respondents it will be used as an information to evaluate the whole study.

\subsection{Statistical Treatment}

The researcher used weighted mean and chi-square to identify the association between student's self-esteem and parental involvement.

\subsection{Data Analysis and Discussion}

Table 1. Self-esteem

\begin{tabular}{lll}
\hline INDICATORS & W.M & INTERPRE \\
\hline On the whole, I am satisfied with myself. & 3.20 & Agree \\
At times, I am not good at all. & 2.85 & Agree \\
I feel that I have a number of good qualities. & 2.88 & Agree \\
I am able to do things as well as most other people. & 2.98 & Agree \\
I feel I did not have much to be proud of. & 2.73 & Agree \\
I certainly feel useless at times. & 2.76 & Agree \\
I feel that I am a person of worth at least on an equal plane with others. & 2.87 & Agree \\
I wish I could have more respect from myself. & 3.08 & Agree \\
All in all, I am inclined to feel that I am a failure. & 2.65 & Agree \\
I take a positive attitude toward myself. & 3.16 & Agree \\
Overall Weighted Mean & 2.92 & Agree \\
\hline
\end{tabular}

Source: Rosenberg, M. (1965). Society and the adolescent self-image. Priceton, NJ: Priceton University Press. Legends: 1.00-1.75(Strongly Disagree), 1.76-2.50(Disagree), 2.51-3.25(Agree) \& 3.26-4.00(Strongly Agree). 


\section{Macrothink}

The result above show ten indicators, indicator 1 have the highest weighted mean (3.20) that corresponds to satisfaction with their self. Indicator 10 is the second highest weighted mean (3.16) that corresponds on taking positive attitudes towards self. Indicator 8 is the third highest weighted mean (3.08) that corresponds to having more self-respect. Rest of the indicators show the range of lowest indicators of weighted mean and this indicate to Indicator 6 with a weighted mean (2.76) corresponds to feeling useless. Indicator 5 with a weighted mean (2.75) corresponds to have much to be proud of and Indicator 9 with the lowest weighted mean (2.92) corresponds to tend to feel a failure. The overall weighted mean of the Table 1 is 2.92 which interpreted into agree.

According to Maduagwu (2014) the higher the level of self-esteem the higher the academic performances while the lower self-esteem results to lower academic performance. Greenacre (2014) said, students who have greater high self-esteem perceive more and have the ability to influence to others. Tripathy (2012) hence, academic achievement affects the self-confidence, inferiority and insecurity feeling.

\begin{tabular}{lll}
\multicolumn{2}{l}{ SELF-ESTEEM } \\
\hline Indicators & Frequency & Percent \\
\hline $1-10$ & 0 & 0 \\
$11-20$ & 3 & 1.2 \\
$21-30$ & 149 & 62.1 \\
$31-40$ & 73 & 30.4 \\
Total & 225 & 93.8
\end{tabular}

Note. SCALE: 1-10 (Strongly Disagree), 11-20 (Disagree), 21-30 (Agree), 31-40 (Strongly Agree).

The first table shows the level of self-esteem of the senior high school students. The highest percentage is $62.1 \%$ in which students agree that having a high self-esteem is helping them to achieve high academic performance that was answered by 149 students. The second highest percentage of the frequency is $30.4 \%$ in which students strongly agree that having a high self-esteem can lead to aim high academic performance. Students who have a high self-esteem will go through a very excellent academic performance (Arshad, Zaidi \& Manhood, 2015). Students who have more self-esteem intend more academic achievement than low academic achiever students (Tripathy, 2012). Students who have more self-esteem intend more academic achievement than low academic achiever students (Tripathy, 2012). 
Table 2. Parental involvement

\begin{tabular}{|c|c|c|}
\hline INDICATORS & W.M & INTERPRE \\
\hline I help my child with his/her homework. & 3.16 & Agree \\
\hline $\begin{array}{l}\text { I set a date to have conferences with my child's teacher about } \\
\text { reading progress. }\end{array}$ & 3.06 & Agree \\
\hline I go to educational activities for parents at school. & 3.16 & Agree \\
\hline I am always attending in Parents Teachers Association Meetings. & 3.17 & Agree \\
\hline $\begin{array}{l}\text { I help my child to learn more through the use of educational } \\
\text { materials at home (Games, magazines, books, newspapers) }\end{array}$ & 3.21 & Agree \\
\hline $\begin{array}{l}\text { I control the amount of time of my child watching TV and any } \\
\text { type of programs. }\end{array}$ & 3.13 & Agree \\
\hline I help my child to add words to his/her speaking vocabulary. & 3.19 & Agree \\
\hline I encourage my child to make conversation in our home. & 3.26 & Strongly Agree \\
\hline $\begin{array}{l}\text { I encourage my child to read books, magazine, and other } \\
\text { educational materials every day. }\end{array}$ & 3.24 & Agree \\
\hline I encourage my child to write every day. & 3.22 & Agree \\
\hline Overall Weighted Mean & 3.18 & Agree \\
\hline
\end{tabular}

Source: https://www.ablongman.com/edwardsliteracyle/

Legends: 1.00-1.75 (Strongly Disagree), 1.76-2.50 (Disagree), 2.51-3.25 (Agree) \& 3.26-4.00 (Strongly Agree).

The table above reveal the answers of the following indicators, Indicator 8 have the highest weighted mean (3.26) that corresponds that parents encourage their child to make or have conversation at home. The second highest weighted mean is Indicator 9 (3.24) corresponds that parents encourage their child to read educational materials every day. The third highest weighted mean is Indicator 10 (3.22) corresponds to parents to encourage their child to write every day. The remaining indicators reveal the range of lowest indicators of weighted mean and this indicates to indicator 1 and 3 (3.16) corresponds to helping the child with homework and attending education activities of parents at school. Indicator 6 with a weighted mean (3.13) correspond to controlling the any type of program such as TV and Indicator 2 with the lowest weighted mean (3.06) corresponds to arranging conference with the teachers about the reading progress. The overall weighted mean of Table 2 is 3.18 which interpreted to AGREE.

Ruholt, Gore and Dukes (2015) shown that parental support has a positive correlation with student's self-esteem in the classroom. Obico (2015) said, students who have good foundation at home perform well than to the students who lack self-esteem. Gith (2017) mothers have more parental involvement to their child than their fathers. 


\begin{tabular}{lll}
\multicolumn{3}{l}{ PARENTAL INVOLVEMENT } \\
\hline Indicator & Frequency & Percent \\
\hline $1-10$ & 0 & 0 \\
$11-20$ & 6 & 2.5 \\
$21-30$ & 81 & 33.8 \\
$31-40$ & 138 & 57.5 \\
Total & 225 & 93.8 \\
\hline
\end{tabular}

Note. SCALE: 1-10 (Strongly Disagree), 11-20 (Disagree), 21-30 (Agree), 31-40 (Strongly Agree).

The table shows that the highest percentage of the level of parental involvement is $57.5 \%$, senior high school students says that they are strongly agree in having a strong relationship of parental involvement can lead to attain high academic performance. The second highest percentage of the frequency is $33.8 \%$ says that the students agree of having parent-child relationship can lead to attain high academic performance. Parents taking control the homework of their students have better communication with their child (Fernandez-Alonso, 2017). When parents involved themselves effectively in child's education, this will give benefits to their child's school performance such as tends to achieve more, better self-esteem, positive attitude and more disciplined (Sapungan, 2014). Parental involvement helps to mold their child, it helps to make learning for children and encourages them to work more (Ntekane, 2018).

Table 3. Self-esteem and parental involvement

\begin{tabular}{llll}
\hline & Value & df & Asymp. Sig. (2-sided) \\
\hline Pearson Chi-Square & $4.223 \mathrm{E2}^{\mathrm{a}}$ & 396 & .174 \\
Likelihood Ratio & 293.218 & 396 & 1.000 \\
Linear-by-Linear Association & 5.216 & 1 & .022 \\
N of Valid Cases & 225 & & \\
\hline
\end{tabular}

Note. a. 437 cells $(100.0 \%)$ have expected count less than 5 . The minimum expected count is .01 .

The table above shows that the p-value (.174) is greater than the alpha (0.05). The decision is failed to reject Ho and there is no significant relationship between the two variables self-esteem and parental involvement. Therefore, there is an association between the student's self-esteem and parental involvement.

According to Ruholt, Gore and Dukes (2015), reveals that parental involvement helps to contribute to build the self-esteem and academic self-efficient of a student. Koskei (2014) Hence, there's a negative relationship between the parental involvement and academic performance. Koskei (2014), Involvement of parents did not significantly influence their 
child, may be parents exerted pressure to get higher grades their child.

\section{Findings}

The data reveal that the self-esteem of the students affects their academic performance; students with high self-esteem tend to be more confident than the students who have low self-esteem. In addition, students with high academic achievement tend to feel more confident in contrast to these who lack of confidence achieves less. Base on the interpreted data, student's self-esteem is interpreted as agree and parental involvement is interpreted as agree.

Student's self-esteem and parental involvement are correlated to each other. Those parents who motivate their child can lead to have a higher self-esteem. If a child has higher self-esteem it will improve their academic performance at school. Hence, those parents who aren't involving themselves to their child's education can lead to lower self-esteem and it will affect their child's academic performance.

\section{Conclusion}

The study reveals that having a higher self-esteem and having a parental involvement helps to mold and attain higher academic performance by the students in school. Parents who were always involved by their child's education are likely to have higher self-esteem [17]. Mean to say, there's a correlation between the self-esteem and parental involvement. If a student has high self-esteem it may lead to high academic achievement than to the students who have lack of self-esteem. Parents also needs to support their child not only by financial but also in supporting and guiding them to their education. Self-esteem and parental involvement is one of the factors to attain higher academic achievement, it results to having a correlation between the self-esteem and parental involvement.

\section{Recommendation}

Based on the finding of the study, students can identify their level of self-esteem and parental involvement; they can use it in boosting their self-esteem and giving more information on how to improve their school performance with the help of parental involvement.

Parents can guide their children to help maintain having a self-esteem by the help of this study.

Teachers can also give guidance to their students on how to build and improve student's self-esteem and made them realize that parental involvement is one of the factors that they have a high self-esteem.

\section{References}

Alavijeh, M. M., Rajati, F., \& Limoee, M. (2018). Self-esteem and academic achievement among students of kermanshah university of medical sciences. Educational Research Medical Sciences, 7(1). https://doi.org/10.5812/erms.79919

Alias, M. (2009). The relationship between academic self-confidence and cognitive 
performance among engineering students. Proceedings of the Research in Engineering Education Symposium. Retrieved from https://www.reserachgate.net/publication/245587102.

Arshad, M., Zaidi, S., \& Mahmood, K. (2015). Self-esteem \& academic performance among university students. Journal of Education and Practice. 6(1).

Aryana, M. (2010). Relationship between self-esteem and academic achievement amongst pre-university students. Journal of Applied Sciences, 10(20), 2474-2477. https://doi.org/10.3923/jas.2010.2474.2477

Doodman, P., Zadeh, M. A., \& Changizi, B. (2017). Study the relationship between self-esteem and academic achievement among high school students. International Journal of Scientific Study.

Durisic, M., \& Bunijevac, M. (2017). Parental Involvement as an important factor for successful education. CEPS JOURNAL, 7(3). Retrieved from https://files.eric.edu.gov/fulltext/EJ1156936.pdf\&ved

Fan, W., \& Williams, C. M. (2010). The effects of parental involvement on students' academic self - efficacy, engagement and intrinsic motivation. Educational Psychology, 30(1), 53-74. https://doi.org/10.1080/01443410903353302

Fernandez-Alonso, R., Alvarez-Diaz., M., Waitschach, P., Suarez-Alvarez, J., \& Cuesta, M. (2017). Parental involvement and academic performance: Less control and more communication. Psicothema, 29(4), 453-461.

Gith, E. (2017). The impact of parental involvement in schools on the self-esteem of Arab children in Israel. International Journal of Humanities and Social Science, 7(3). Retrieved from https://www.semanticscholar.org

Greenacre, L. (2014). Self-confidence and the ability to influence. Academy of Marketing Study Journal, 18(2), 169-180. https://www.researchgate.net /publication/286318041.

Hill, N., \& Taylor, L. C. (2004). Parental school involvement and children's academic Achievement. American Psychological Society, 13(4), 161-164. https://doi.org/10.1111/j.0963-7214.2004.00298.x

Khajehpour, M., \& Ghazini, S. D. (2011). The role of parental involvement affects in children's academic performance. Procedia Social and Behavioral Sciences, 1204-1208. https://doi.org/10.1016/j.sbspro.2011.03.263

Koskei, B. K. (2014). Influence of parental involvement on student's academic performance of public mixed day secondary schools. International Journal of Education and Research, 2(12). Retrieved from https://www.semanticscholar.org/

Maduagwu, S., \& Maduagwu, B. C. (2014). Relationship between academic self-esteem and performance in English language and mathematics of primary school pupils. Journal of Education Foundation, 4(1). Retrieved from https://reserachgate.net./publication/313755248

Mcneal, R. (2014). Parent Involvement, Academic Achievement and the Role of student 
Attitudes and Behaviors as mediators. Universal Journal of Education Research, 2(8), 564-576.

Mello, L., Monteiro, M., \& Pinto, N. (2017). A study on the self-esteem and academic performance among the students. International Journal of Health Sciences and Pharmacy, 2(1), 1-7.

Ntekane, A. (2018). Parental involvement in education. Research Gate Journal.

Obico, K. (2013). Impact of parental involvement on student achievement. Retrieved from http://www.nwmissouri.edu /library/Obico,\%2520Kent.

Orth, U., \& Robins, R. W. (2014). The development of self-esteem. Association for Psychological Science, 23(5), 381-387. https://doi.org/10.1177/0963721414547414

Ratnasari, S. D., \& Andriansyah, A. S. (2014). Effects of self-confidence and self-assessment for performance with social skill as moderating variables. Journal of Business Management, 16(11), 43-47. https://doi.org/10.9790/487X-161164347

Rogers, M., Theule, J., Ryan, B., Adams, G., \& Keating, L. (2009). Parental involvement and children's school achievement. Canadian Journal of School Psychology, 24(1), 34-57. https://doi.org/10.1177/0829573508328445

Rosli, Y., Ishak, I., Orthman, H., \& Lubis, S. (2011). Self-esteem and academic performance relationship amongst the second-year undergraduate students. Procedia Social and Behavioral Sciences, 582-589. https://doi.org/10.1016/j.sbspro.2012.09.426

Ruholt, R., Gore, J., \& Dukes, K. (2015). Is parental support or parental involvement more important for adolescents. Undergraduate Journal of Psychology, 28(1). Retrieved from https://journals.uncc.edu/ujop/article/view/292

Sternke, J. C. (2010). Self-Concept and Self-Esteem in Adolescents with Learning Disabilities. Retrieved from http://www2.uwstout.edu /content/lib/thesis/2010/sternkej.

Tripathy, M. (2012). To study the effect of academic achievement on the level of self-confidence. International Journal of Yoga and Allied Sciences, 1(1).

Vijaya, R. (2016). Parental involvement and academic achievement among high school students. International Journal of Multidisciplinary Research Review, 5(12). Retrieved from https://www.reserachgate.net/publication/317545158.

\section{Glossary}

Self-esteem- a feeling of having respect for yourself and your abilities

Parental involvement- the amount of participation of a parent when it comes to schooling and child's life

\section{Appendix A}

Appendix 1. Survey Questionnaire for the Instructions: Below is a list of statements dealing 


\section{Macrothink}

with your general feelings and yourself. Please check how 4 (Strongly Agree), 3 (Agree), 2 (Disagree), 1 (Strongly Disagree) with each statement

\section{SELF-ESTEEM}

\section{Indicators}

1) On the whole, I am satisfied with myself.

2) At times, I am not good at all.

3) I feel that I have a number of good qualities.

4) I am able to do things as well as most other people.

5) I feel I did not have much to be proud of.

6) I certainly feel useless at times.

7) I feel that I am a person of worth at least on an equal plane with others.

8) I wish I could have more respect from myself.

9) All in all, I am inclined to feel that I am a failure.

10) I take a positive attitude toward myself.

\begin{tabular}{|l|l|l|l|}
\hline 4 & 3 & 2 & 1 \\
\hline & & & \\
\hline & & & \\
\hline & & & \\
\hline & & & \\
\hline & & & \\
\hline & & & \\
\hline & & & \\
\hline & & & \\
\hline & & & \\
\hline & & & \\
\hline
\end{tabular}

\section{PARENTAL INVOLVEMENT}

\section{Indicators}

1) Helping the child with homework.

2) Arranging conferences with my child's teacher about reading progress.

3) Going to education activities for parents at school.

4) Taking part of PTA Meetings. 


\section{Macrothink}

International Journal of Social Science Research

ISSN 2327-5510

2020, Vol. 8, No. 2

5) Helping child learn through the use of educational materials at home (games, magazines, books \& newspapers).

6) Controlling the amount of time child spends watching TV and any type of programs.

7) Helping child add words to his/her speaking vocabulary.

8) Encouraging conversations at home.

9) Encouraging child to read every day.

10) Encouraging child to write every day.

\begin{tabular}{|l|l|l|l|}
\hline 4 & 3 & 2 & 1 \\
\hline & & & \\
\hline & & & \\
\hline & & & \\
\hline & & & \\
\hline & & & \\
\hline & & & \\
\hline & & & \\
\hline & & & \\
\hline & & & \\
\hline & & & \\
\hline
\end{tabular}

\section{Copyrights}

Copyright for this article is retained by the author(s), with first publication rights granted to the journal.

This is an open-access article distributed under the terms and conditions of the Creative Commons Attribution license (http://creativecommons.org/licenses/by/4.0/). 